\title{
RANCANG BANGUN ALAT IMPREGNASI VAKUM DAN UJI PERFORMANSINYA PADA FILET IKAN
}

\section{Design of Vacuum Impregnation Machine and Its Performance Trial on Fish Fillet}

\author{
Arif Rahman Hakim ${ }^{1 *}$, Gunawan ${ }^{1}$, dan Rodiah Nurbaya Sari ${ }^{2}$ \\ ${ }^{1}$ Loka Penelitian dan Pengembangan Mekanisasi Pengolahan Hasil Perikanan, \\ JI. Imogiri Barat KM 11.5 Jetis, Bantul, DI Yogyakarta, Indonesia \\ ${ }^{2}$ Balai Besar Penelitian dan Pengembangan Pengolahan Produk dan Bioteknologi Kelautan dan Perikanan, \\ JI. K.S. Tubun Petamburan VI, Jakarta Pusat, Indonesia \\ * Korespondensi Penulis: arifrahmanh11@gmail.com \\ Diterima: 13 Februari 2014; Disetujui: 23 Mei 2014
}

\begin{abstract}
ABSTRAK
Telah dilakukan penelitian rancang bangun alat impregnasi vakum beserta uji performansinya. Tujuan penelitian ini ialah untuk mendapatkan prototipe alat impregnasi vakum serta hasil pengujian pada filet ikan dalam introduksi larutan osmotik yaitu larutan garam dan larutan asap cair. Komponen utama alat adalah tangki vakum, tangki penyimpan, tangki pengaduk, sistem vakum, pompa pendorong manual, sistem pemindahan bahan dan panel kontrol. Prinsip kerja alat impregnasi vakum adalah mengkondisikan tekanan udara dalam tangki vakum menjadi lebih tinggi maupun lebih rendah dari tekanan normal atmosfer sehingga cairan dalam bahan dapat ditarik keluar dan larutan osmotik dapat dimasukkan untuk menggantikannya. Alat tersebut memiliki kekuatan vakum maksimal $-76 \mathrm{cmHg}$ dalam waktu rata-rata 9,15 menit dan kekuatan tekan /impregnasi maksimal 8 Bar dalam waktu 38,70 menit. Hasil uji performansi alat terhadap filet ikan menunjukkan bahwa larutan osmotik berupa larutan garam dan asap cair dapat terintroduksi ke dalam filet ikan lebih efisien dibandingkan metode perendaman.
\end{abstract}

KATAKUNCl: alat impregnasi vakum, larutan osmotik, filet ikan

\begin{abstract}
Design of vacuum impregnation machine and its performance trial on fish fillet has been conducted. Objective of this research was to obtain a prototype of vacuum impregnation machine and to conduct a performance test to the equipment to introduce brine and liquid smoke into fish fillet. The main components of the machine were vacuum tank, storage tank, mixing tank, vacuum system, manual booster pump, impregnant transfer system and control panel. The working principle of vacuum impregnation machine is to enable the air pressure in the vacuum tank to be higher or lower than normal atmospheric pressure, until the liquid in the material can be taken out and replaced with osmotic solution. The device had a maximum vacuum at $-76 \mathrm{cmHg}$ in 9.15 minutes, with maximum impregnation of 8 Bar in 38.70 minutes. Furthermore, result of performance test on fish fillet showed that osmotic solution (brine and liquid smoke) was able to be introduced on fillet more efficient than immersion methods.
\end{abstract}

KEYWORDS: vacuum impregnation, osmotic solution, fish fillet

\section{PENDAHULUAN}

Impregnasi vakum (vacuum impregnation) adalah suatu metode dalam pengolahan pangan dengan prinsip mengeluarkan sebagian atau keseluruhan udara maupun cairan dalam suatu bahan pangan kemudian menggantikannya dengan cairan atau larutan osmotik yang dikehendaki (Fito, 1994; Laurindo et al., 2007). Saat bahan pangan diberi perlakuan impregnasi vakum, cairan yang ada dalam bahan akan keluar karena kondisi tekanan lingkungan di bawah tekanan atmosfir, bagian-bagian yang kosong tersebut akan terisi kembali oleh cairan lain ketika tekanan dikembalikan pada tekanan atmosfir seperti semula atau lebih tinggi hingga tercapai keseimbangan antara cairan dalam bahan dan lingkungan (Guillemin et al., 2008).

Saat ini metode impregnasi vakum tengah populer sebagai metode untuk pengkayaan (enrichment) produk pangan (Schulze et al., 2012). Penelitian 
sebelumnya (Betoret et al., 2003; Xie and Zhao, 2003; Park et al., 2005), membuktikan bahwa jaringan sel pada buah-buahan bisa diperkaya dengan berbagai bahan seperti probiotik, vitamin, dan mineral tertentu untuk menambah manfaatnya. Metode impregnasi vakum juga dapat memperbaiki rasa, memperpanjang daya simpan (Guamis et al., 1997; Chiralt et al., 2001) dan memperbaiki warna pada produk pangan (Jeon \& Zhao, 2005).

Metode impregnasi vakum berpeluang besar untuk memperbaiki kualitas produk olahan ikan. Hal ini karena daging ikan mempunyai sifat matrik sel yang longgar sehingga proses penggantian cairan dalam daging ikan dengan larutan osmotik akan lebih mudah. Dengan introduksi larutan osmotik yang mempunyai manfaat lebih akan mampu meningkatkan kualitas produk tersebut (komposisi zat tertentu, daya simpan, tekstur, rasa, dan warna). Tujuan dari penelitian ini adalah untuk mendapatkan rancang bangun alat impregnasi vakum dan uji performansi alat tersebut untuk produk filet ikan terutama kemampuannya dalam mengintroduksikan larutan osmotik pada bahan.

Penggunaan larutan garam dan larutan asap cair dipilih dalam uji coba karena prinsipnya lebih sederhana. Saat ini pengolahan ikan asin atau penggaraman dan juga pengasapan ikan membutuhkan waktu yang lama karena penyerapan baik garam maupun asap lambat sehingga beresiko terjadinya kemunduran mutu ikan. Beberapa penelitian melaporkan bahwa teknologi penggaraman secara vakum dapat mempercepat proses tersebut serta menjadikan distribusi garam lebih merata (Barat et al., 1998).

\section{BAHAN DAN METODE}

\section{Bahan Rancang Bangun dan Bahan Uji}

Fungsi utama dari alat vakum tekan ialah kemampuannya untuk mengatur (mengurangi dan meningkatkan) tekanan udara pada ruang sampel, baik di bawah maupun di atas tekanan atmosfer, kemudian mengalirkan larutan osmotik ke sampel. Bagian-bagian utama pada alat vakum tekan antara lain tangki vakum, tangki penyimpanan, tangki pengaduk, sistem pemvakuman, pompa pendorong manual, sistem aliran bahan dan panel kontrol. Semua bagian yang bersentuhan langsung dengan sampel dan larutan osmotik dibuat menggunakan bahan stainless steel (SS) tipe 304.

Bahan yang digunakan untuk uji performansi alat adalah filet ikan nila dengan ukuran 400-500 g/ekor, larutan garam, asap cair, bahan-bahan kimia untuk uji kadar garam dan kadar fenol.

\section{Uji Performansi dan Analisis}

Metode yang digunakan untuk uji performansi alat adalah sebagai berikut: (1) Persiapan sampel, ikan nila segar dengan bobot sekitar 400-500 g/ekor difilet (skinless fillet) kemudian dicuci sampai bersih. Bobot filet tanpa kulit berkisar antara 100-150 g/ekor. (2) Penyiapan larutan osmotik, larutan osmotik yang digunakan terdiri dari larutan garam sebanyak $17,4 \mathrm{~g} /$ liter $(1,74 \%)$ dan asap cair 1,5\% (Bugueno et al., 2001). (3) Proses impregnasi, larutan garam dan asap cair yang telah dibuat dimasukkan ke dalam rangkaian alat impregnasi vakum yaitu pada tangki pencampur, kemudian dilakukan homogenisasi sampai merata dan dipindahkan ke tangki penampung yang berada di bagian paling atas alat menggunakan pompa dorong. (4) Filet ikan nila dimasukkan ke tangki vakum dan ditutup dengan rapat. Setelah bahan dan larutan osmotik siap pada tempatnya masing-masing, proses vakum dimulai dengan menurunkan tekanan udara pada tangki vakum. Tekanan vakum diatur maksimal hingga $-76 \mathrm{cmHg}$. Proses impregnasi vakum ini dilakukan pada suhu ruang. Setelah tekanan vakum tercapai, proses penyedotan udara dihentikan dan dibiarkan selama 5 dan 10 menit. (5) Tekanan udara tangki vakum di kembalikan pada kondisi semula (0 $\mathrm{cmHg}$ ). Kemudian larutan garam dan asap cair dimasukkan ke dalam tangki vakum hingga sampel terendam, lalu diberi penambahan tekanan/impregnasi dalam tangki tersebut dengan variasi 0, 1 dan 2 Bar, dengan lama waktu proses impregnasi 5, 15, dan 25 menit. Filet ikan nila dianalisis kadar garam (Metode SNI 01-2359 - 1991 dalam BSN, 1991) dan kadar fenolnya (SMEWW 21th (2005): 5530-Phenols).

Sebagai pembanding juga dilakukan perlakuan dengan metode perendaman. Filet ikan direndam dalam campuran larutan garam sebanyak $17,4 \mathrm{~g} / \mathrm{liter}$ $(1,74 \%)$ dan asap cair $1,5 \%$ selama 60 menit dengan perbandingan bahan dan larutan 1:2 (b/v). Kemudian dilakukan uji kadar fenol dan garam terhadap filet ikan tersebut.

Uji performansi dilakukan menggunakan rancangan acak lengkap (RAL) dengan masing-masing perlakuan 3 (tiga) kali ulangan.

\section{HASIL DAN PEMBAHASAN}

\section{Perancangan Alat Impregnasi Vakum}

Alat impregnasi vakum dirancang dengan dimensi panjang $800 \mathrm{~mm}$, lebar $570 \mathrm{~mm}$ dan tinggi $1740 \mathrm{~mm}$. Dalam pembuatan rangka digunakan bahan besi hollow $4 \times 4 \mathrm{~cm}$, sedangkan semua bagian yang bersentuhan langsung dengan larutan garam, asap cair dan sampel di gunakan bahan baja tak berkarat 


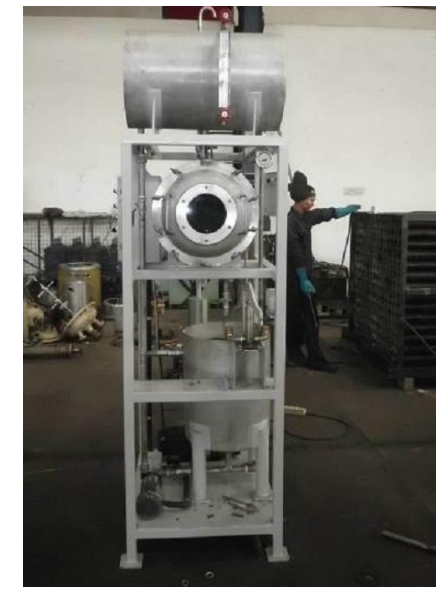

Tampak Depan/ Front View

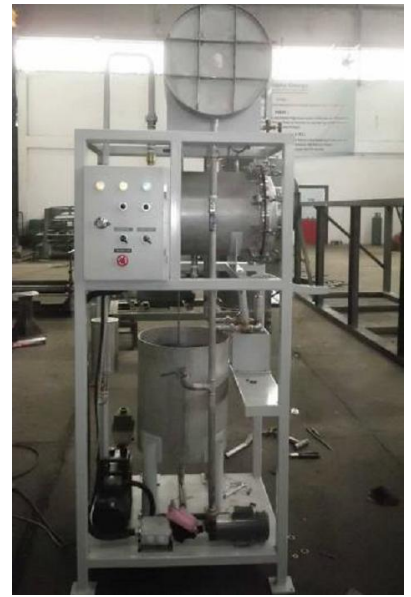

Tampak Samping/

Side View

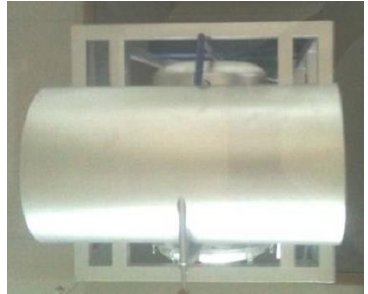

Tampak Atas/

Top View

Gambar 1. Alat impregnasi vakum.

Figure 1. Vacuum impregnation machine.

304. Dibuat 3 tangki atau tabung yaitu tangki penyimpanan, tangki vakum, dan tangki pengaduk, masing-masing mempunyai kapasitas 130,70 , dan $60 \mathrm{I}$. Alat impregnasi vakum dapat dilihat pada Gambar 1 , sedangkan desain alat impregnasi vakum dapat dilihat pada Gambar 2.

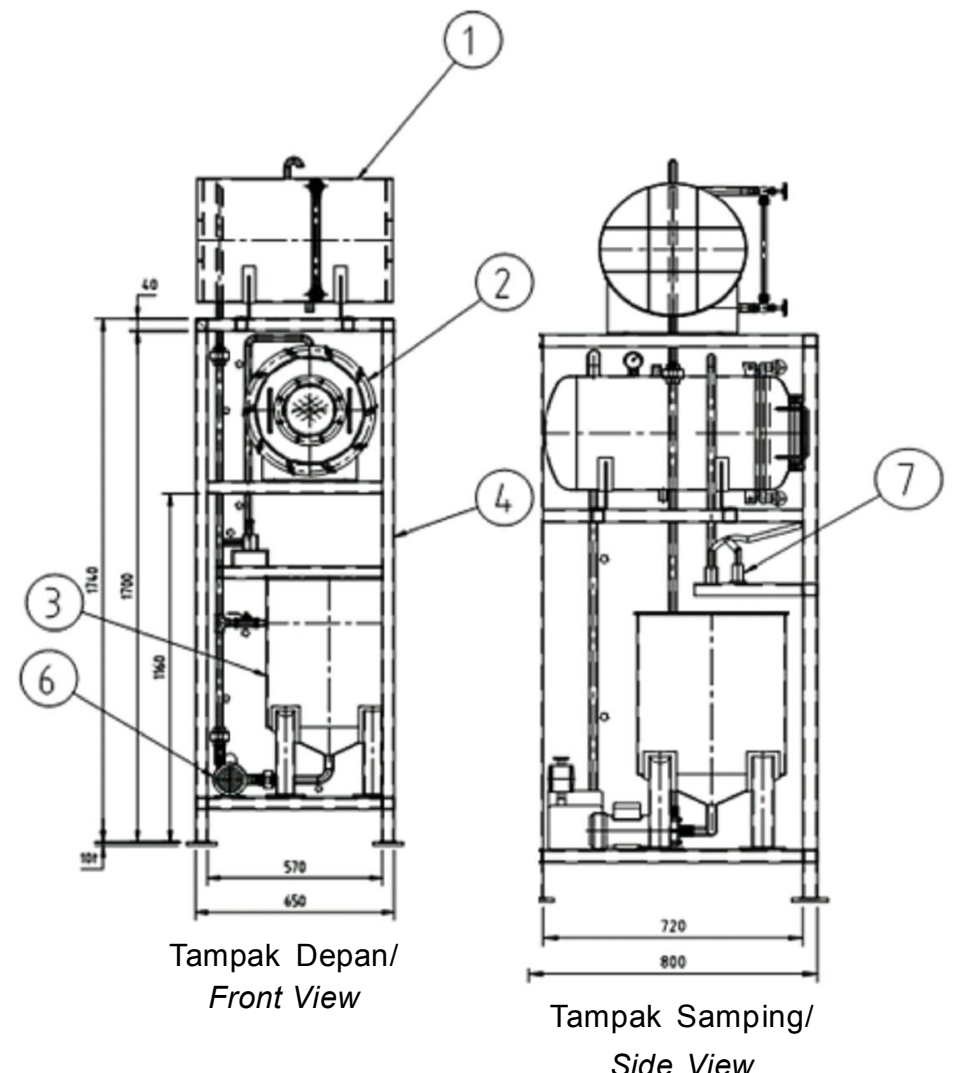

\section{Tangki Penyimpan}

Tangki penyimpan berfungsi untuk menampung larutan-larutan osmotik yang akan diintroduksikan ke sampel atau bahan. Tangki penyimpanan diletakkan pada bagian atas alat impregnasi vakum, agar transfer
Keterangan/Note:

1. Tangki penyimpan/Storage tank

2. Tangki vakum/Vacuum tank

3. Tangki Pengaduk/Mixing tank

4. Rangka besi/Frame-iron

5. Pompa vakum/Vacuum pump

6. Pompa pengalir/Transfer pump

7. Pompa pendorong manual/ Manual booster pump

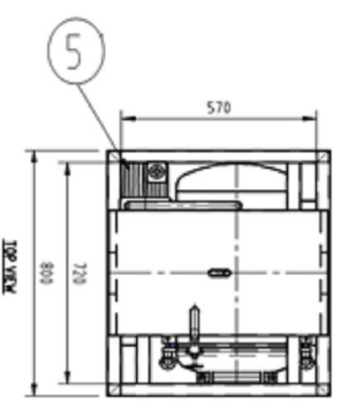

Tampak Atas/

Top View

Gambar 2. Desain alat impregnasi vakum.

Figure 2. Design of vacuum impregnation machine. 
larutan ke dalam tangki vakum dapat dilakukan dengan cara gravitasi. Tangki penyimpan didesain dengan diameter $400 \mathrm{~mm}$ dan panjang $570 \mathrm{~mm}$, mempunyai kapasitas yang lebih besar dibandingkan tangki vakum dengan tujuan agar dapat memenuhi jumlah larutan maksimal yang dapat ditampung dalam tangki vakum. Tangki penyimpan dilengkapi dengan pipa kaca pengukur ketinggian air serta pipa over flow untuk menghindari kelebihan pengisian larutan osmotik dalam tangki.

\section{Tangki Vakum}

Dimensi ukuran tangki vakum yang dibuat adalah panjang $550 \mathrm{~mm}$ dan diameter $340 \mathrm{~mm}$. Tangki vakum dirancang mampu menahan tekanan hingga 8 Bar dan kondisi vakum hingga $-76 \mathrm{cmHg}$. Pada bagian dalam tangki vakum dilengkapi dengan rak/tray untuk meletakkan sampel padat. Penutup diletakkan pada bagian depan sehingga memudahkan pengoperasiannya serta dilengkapi kaca agar bisa melihat kondisi sampel saat alat dioperasikan.

Dari hasil uji performa alat diperoleh rata-rata waktu yang dibutuhkan untuk mencapai tekanan maksimal dalam kondisi dengan bahan dan tanpa bahan yang dapat dilihat pada Tabel 1 .
Tabel 1 menunjukkan bahwa dibutuhkan waktu lebih lama untuk mendapatkan tekanan udara lebih tinggi dalam tangki vakum. Selanjutnya jika dibandingkan antara tangki vakum yang didalamnya terdapat bahan maupun tidak, maka waktu yang dibutuhkan untuk mencapai tekanan udara tertentu akan lebih lama bila terdapat bahan (sampel) didalamnya. Untuk mendapatkan tekanan udara hingga 8 Bar dibutuhkan waktu rata-rata 38,70 menit (tanpa bahan) dan 67,03 menit (dengan bahan).

Fenomena tersebut terjadi karena faktor yang mempengaruhi peningkatan tekanan udara pada ruang ialah kerapatan udara untuk meningkatkan kerapatan udara dibutuhkan waktu yang lebih lama (Hong et al., 2013). Hal ini juga sesuai dengan Hukum Gas Charles (Burg, 2014), bahwa kerapatan udara akan berbanding lurus dengan tekanan pada temperatur konstan dan kerapatan udara akan berbanding terbalik dengan temperatur pada tekanan konstan.

Waktu yang dibutuhkan untuk mencapai kehampaan udara/kevakuman pada tangki dapat dilihat pada Tabel 2.

Pada uji alat impregnasi vakum, tekanan udara terendah yang dicapai ialah $-76 \mathrm{cmHg}$ dalam waktu rata-rata 9,15 menit, sedangkan bila terdapat

Tabel 1. Rata-rata kebutuhan waktu untuk proses impregnasi

Table 1. Average time required for impregnation process

\begin{tabular}{ccc}
\hline \multirow{2}{*}{$\begin{array}{c}\text { Tekanan Udara/ } \\
\text { Atmospheric Pressure (Bar) }\end{array}$} & \multicolumn{2}{c}{ Waktu (menit)/Time (minutes) } \\
\cline { 2 - 3 } & $\begin{array}{c}\text { Tanpa Bahan/ } \\
\text { Without Sample }\end{array}$ & $\begin{array}{c}\text { Dengan Bahan/With Sample } \\
(\mathbf{4 5 0 - 4 6 0 )} \mathbf{g}\end{array}$ \\
\hline 2 & $4.50 \pm 1.30$ & $7.46 \pm 2.10$ \\
4 & $11.25 \pm 3.20$ & $32.29 \pm 9.30$ \\
6 & $23.29 \pm 6.70$ & $51.38 \pm 14.70$ \\
8 & $38.70 \pm 11.10$ & $67.03 \pm 19.20$ \\
\hline
\end{tabular}

Table 2. Rata-rata kebutuhan waktu untuk proses vakum

Table 2. Average time required for vacuum process

\begin{tabular}{ccc}
\hline \multirow{2}{*}{$\begin{array}{c}\text { Tekanan Udara/ } \\
\text { Atmospheric Pressure (Bar) }\end{array}$} & \multicolumn{2}{c}{ Waktu (menit)/Time (minutes) } \\
\cline { 2 - 3 } & $\begin{array}{c}\text { Tanpa Bahan/ } \\
\text { Without Sample }\end{array}$ & $\begin{array}{c}\text { Dengan Bahan/With Sample } \\
(\mathbf{4 5 0 - 4 6 0 )} \mathbf{~ g}\end{array}$ \\
\hline-25 & $2.90 \pm 0.90$ & $3.88 \pm 0.60$ \\
-50 & $6.18 \pm 1.80$ & $8.68 \pm 1.10$ \\
-76 & $9.15 \pm 1.70$ & $13.75 \pm 1.0$ \\
\hline
\end{tabular}


sampel dalam tangki dibutuhkan waktu selama 13,75 menit.

Untuk mendapatkan tekanan udara lebih rendah dari tekanan atmosfer maka dilakukan pengurangan jumlah udara dalam ruangan/tangki. Penghisapan udara dilakukan secara mekanis menggunakan bantuan pompa hisap/vakum. Semakin banyak udara yang dibuang (tekanan semakin rendah) maka semakin lama waktu yang dibutuhkan. Demikian pula bila dalam tangki terdapat bahan/sampel maka waktu yang dibutuhkan semakin lama karena udara dalam bahan berada pada pori-pori bahan sehingga lebih sulit di keluarkan.

\section{Tangki Pencampur}

Bagian utama lain pada alat impregnasi vakum adalah tangki pencampur. Fungsi tangki pencampur adalah sebagai tempat untuk homogenisasi larutan osmotik sebelum dimasukkan ke dalam tangki penyimpan dan juga berfungsi sebagai tangki penampung larutan osmotik yang telah terpakai dari tangki vakum. Tangki ini dibuat sedikit mengerucut pada bagian bawah, yang berfungsi agar proses homogenisasi dengan memutar larutan berjalan lebih mudah, demikian pula saat proses pembuangan larutan osmotik yang sudah tidak terpakai. Tangki pencampur memiliki ukuran diameter $400 \mathrm{~mm}$ dan tinggi $500 \mathrm{~mm}$.

\section{Sistem Vakum}

Pompa vakum digunakan untuk mendapatkan tekanan di bawah tekanan atmosfer atau kondisi vakum. Pada pembuatannya digunakan pompa sentrifugal yang dimodifikasi dengan penambahan aliran air pada putaran pompa, yang diharapkan mampu mengurangi panas pada pompa saat digunakan. Pompa sentrifugal yang digunakan berkekuatan $2 \mathrm{HP}$.

\section{Pompa Pendorong Manual}

Pompa pendorong manual adalah bagian dari alat vakum tekan yang berfungsi untuk menambah tekanan pada tangki vakum. Dengan alat manual ini, penambahan tekanan akan lebih mudah karena tekanan akan bertambah secara perlahan-lahan. Prinsip kerja dari pompa pendorong seperti pompa hidrolik, yaitu menambah tekanan dalam tangki vakum dengan tekanan udara yang dipompakan.

Pompa pendorong dipasang pada pipa antara tangki penyimpan dan tangki vakum. Pipa tersebut berdiameter $1 / 4$ inci dengan bahan besi anti karat. Pada ujung-ujung pipa dipasang check valve sehingga udara yang dimasukkan ke dalam tangki vakum tidak kembali ke luar. Pompa yang digunakan ialah jenis piston silinder tunggal berdiameter $1 / 4$ inci dan dilengkapi seal karet agar udara tidak bocor dari dalam silinder.

\section{Sistem Pemindahan Bahan}

Sistem pemindahan bahan (impregnant transfer system) ialah sistem perpindahan larutan osmotik dari tangki pengaduk ke tangki penyimpan maupun ke tangki vakum. Sistem ini terdiri atas pompa transfer, pipa-pipa dan kran. Energi pompa yang digunakan sebesar 0,065 kWh. Sedangkan pipa baja tak berkarat yang digunakan berdiameter $1 / 2$ inci.

\section{Panel Kontrol}

Sentralisasi panel kontrol pada alat vakum tekan akan memudahkan pengoperasian dan keamanannya. Panel kontrol dilengkapi lampu penunjuk power 3 phase, lampu penunjuk pompa transfer dan pompa vakum, tombol on/off pompa transfer dan pompa vakum serta tombol keadaan darurat yang apabila terjadi kesalahan pengoperasian, dapat memutus semua arus listrik.

\section{Uji Performansi}

Untuk mengetahui performansi alat vakum tekan dilakukan introduksi larutan osmotik berupa larutan garam $(1,74 \%)$ dan asap cair $(1,5 \%)$ ke dalam filet ikan nila. Hasil pengamatan adalah sebagai berikut.

\section{Kadargaram}

Kadar garam pada filet ikan sebelum dilakukan proses vakum tekan rata-rata adalah $0,4 \%$, setelah perlakuan impregnasi vakum kadar garam pada filet nila meningkat menjadi $0,78-1,65 \%$. Pada uji ini tekanan yang digunakan dibuat sama yaitu 2 Bar dan tingkat vakum $-76 \mathrm{cmHg}$. Pengaruh impregnasi vakum dengan introduksi larutan garam terhadap kadar garam filet ikan dapat dilihat pada Gambar 3.

Rata-rata kadar garam filet yang mendapatkan perlakukan vakum 10 menit lebih tinggi $(p<0,05)$ dibandingkan dengan perlakuan vakum selama 5 menit. Sedangkan filet dari perlakuan lama waktu tekan 15 menit memiliki kadar garam yang lebih tinggi di bandingkan dengan perlakuan lain. Berdasarkan SNI 2721.1:2009 dalam BSN, 2009 tentang standar mutu ikan asin, kadar garam pada ikan asin ialah 10$20 \%$, sehingga nilai kadar garam yang terdapat pada sampel masih di bawah standar mutu tersebut. Namun peluang untuk mencapai kadar tersebut dengan waktu lebih singkat cukup besar karena sample pada penelitian dalam keadaan tidak kering/kadar air cukup tinggi dan larutan garam yang digunakan hanya $1,74 \%$. 


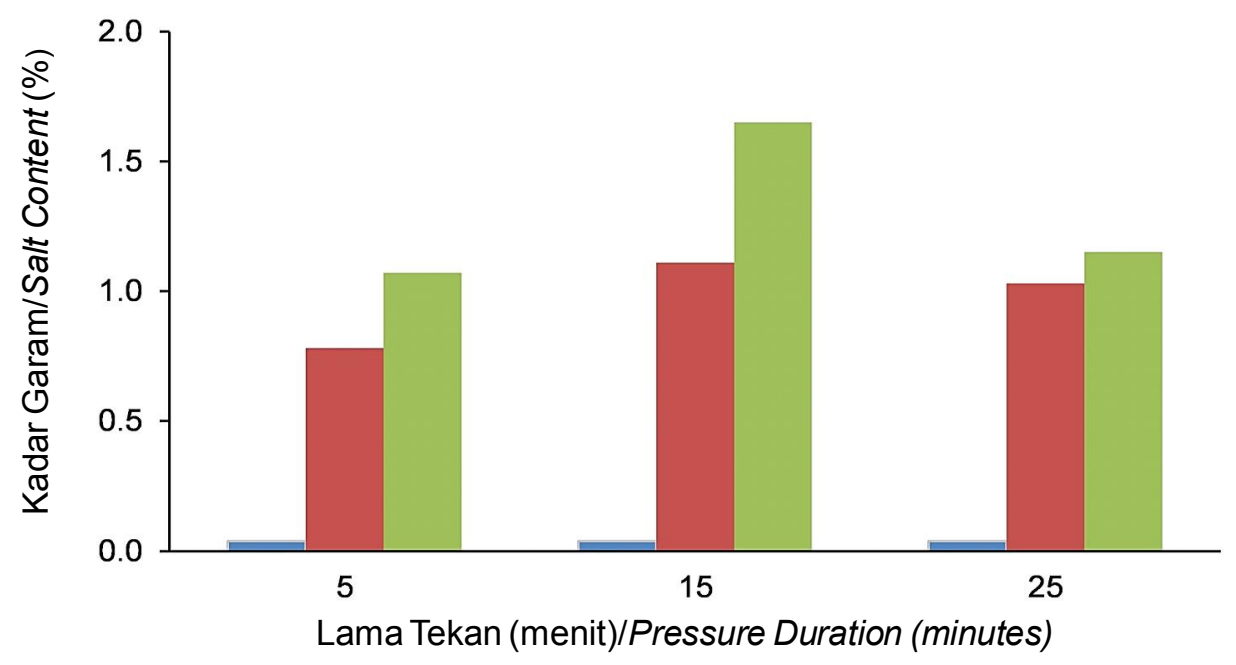

- Tanpa impregnasi vakum/Without vacuum impregnation
- Lama vakum 5 menit/Vacuum duration 5 minutes
— Lama vakum 10 menit/Vacuum duration 10 minutes

Keterangan/Note: tingkat impregnasi 2 Bar/impregnation level 2 Bar tingkat vakum $-76 \mathrm{cmHg} /$ vacuum level $-76 \mathrm{cmHg}$

Gambar 3. Pengaruh lama waktu vakum dan tekan terhadap kadar garam filet ikan. Figure 3. Effect of vacuum and pressure periods on the salt content of fish fillet.

Sedangkan dengan metode perendaman, pada penelitian Rahmani et al. (2007) dengan sampel ikan gabus menggunakan larutan garam sebanyak $40 \%$ membutuhkan waktu 12 jam untuk menghasilkan ikan gabus asin dengan kadar garam $7,93 \%$. Pada penelitian lain Chaijan (2011) menyebutkan bahwa penggaraman basah pada ikan nila dengan larutan $\mathrm{NaCl} 25 \%$ selama 3 jam akan menghasilkan 5,3\% kadar garam.

Dengan waktu vakum lebih lama, pengeluaran udara dan air bebas pada filet ikan akan lebih banyak, sehingga saat larutan osmotik ditambahkan penyerapan filet ikan terhadap larutan tersebut akan lebih banyak. Menurut Chiralt et al. (2001) dan Silvana et al. (2006), lama waktu vakum pada proses impregnasi vakum membutuhkan lama waktu tertentu tergantung pada jumlah udara dan air bebas pada bahan. Akibatnya, pada waktu vakum lebih lama, larutan osmotik yang masuk ke bahan menjadi lebih banyak karena struktur bahan akan menyeimbangkan dengan kondisi/konsentrasi larutan di lingkungan tersebut.

\section{Kadar fenol}

Kadar fenol filet ikan berkisar antara 9,68-17,10 $(\mathrm{mg} / \mathrm{kg})$. Kadar fenol tertinggi dihasilkan dari perlakuan vakum selama 5 menit dan lama tekan selama 5 menit yaitu sebesar 17,10 (mg/kg) (Gambar 4). Perlakuan lama tekan 5 menit menyebabkan terjadinya perbedaan pola kadar fenol filet dibandingkan dengan perlakuan lainnya, yaitu terdapat kecenderungan penurunan kadar fenol jika filet ikan diberi perlakuan waktu vakum lebih lama, dan kondisi tersebut berlawanan dengan perlakuan lainnya.

Menurut Laurindo et al. (2007) bahwa di dalam dinamika penyerapan larutan osmotik pada proses impregnasi vakum, yang berpengaruh paling besar terhadap penyerapan larutan osmotik adalah besarnya kekuatan vakum dan tekanan atmosfer, sedangkan lama waktu keduanya tidak memberikan pengaruh nyata.

Pada penelitiannya Serot et al. (2004) menyatakan bahwa filet ikan hering yang direndam menggunakan asap cair selama 4 jam suhu $24^{\circ} \mathrm{C}$ menghasilkan kandungan fenol sebanyak $4 \mathrm{mg} / 100 \mathrm{~g}$. Pada penelitian Cardinal et al. (2001) terlihat bahwa kadar fenol filet ikan salmon yang diberi perlakuan pengasapan dengan metode tradisional selama 30 menit ialah sebesar $0,75-1,2 \mathrm{mg} / 100 \mathrm{~g}$. Sedangkan dengan menggunakan alat vakum impregnasi selama 10 menit (vakum dan impregnasi) mampu dihasilkan kadar fenol sebanyak 1,7 mg/100 g. Hal ini menunjukkan bahwa penggunaan alat vakum impregnasi lebih efisien dalam membantu proses penyerapan larutan asap cair pada filet ikan. Standar mutu produk asap menurut Girard (1992) maksimal kandungan fenol ialah $0,5 \%$ atau $500 \mathrm{mg} / 100 \mathrm{~g}$. 


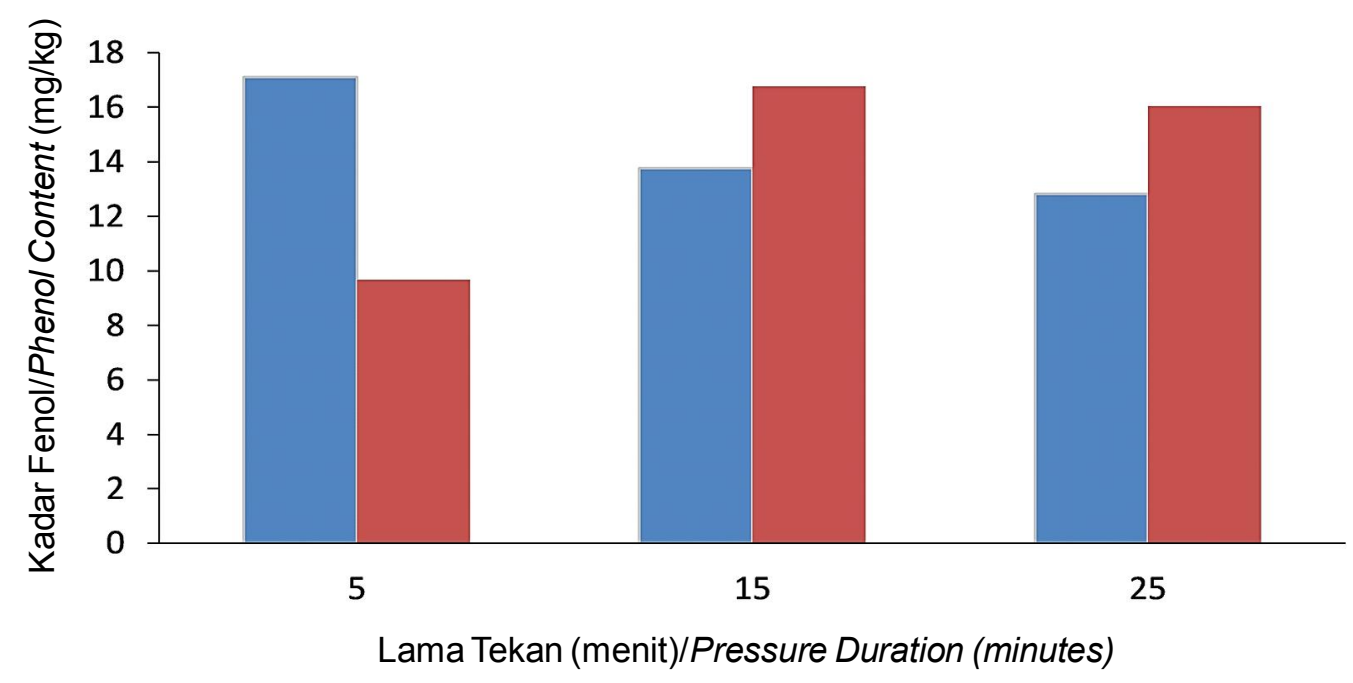

[ Lama vakum 5 menit/Vacuum duration 5 minutes

- Lama vakum 10 menit/Vacuum duration 10 minutes

Keterangan/Note: tingkat impregnasi 2 Bar/Impregnation level 2 Bar tingkat vakum $-76 \mathrm{cmHg} /$ Vacuum level $-76 \mathrm{cmHg}$

Gambar 4. Pengaruh lama waktu vakum dan tekan terhadap kadar fenol filet ikan. Figure 4. Effect of vacuum and pressure periods to the fenol content of fish fillet.

\section{Pengaruh tekanan}

Pengaruh perbedaan kekuatan tekan dalam waktu 15 menit dan lama vakum 10 menit, terhadap kadar garam dan fenol pada filet ikan tersaji pada Gambar 5.
Besar tekanan pada proses impregnasi vakum memberikan pengaruh nyata $(p<0,05)$ terhadap kadar garam dan fenol filet ikan. Semakin besar tekanan yang diberikan menyebabkan introduksi larutan osmotik ke dalam matrik daging ikan akan semakin banyak. Igual et al. (2008) menyatakan besarnya

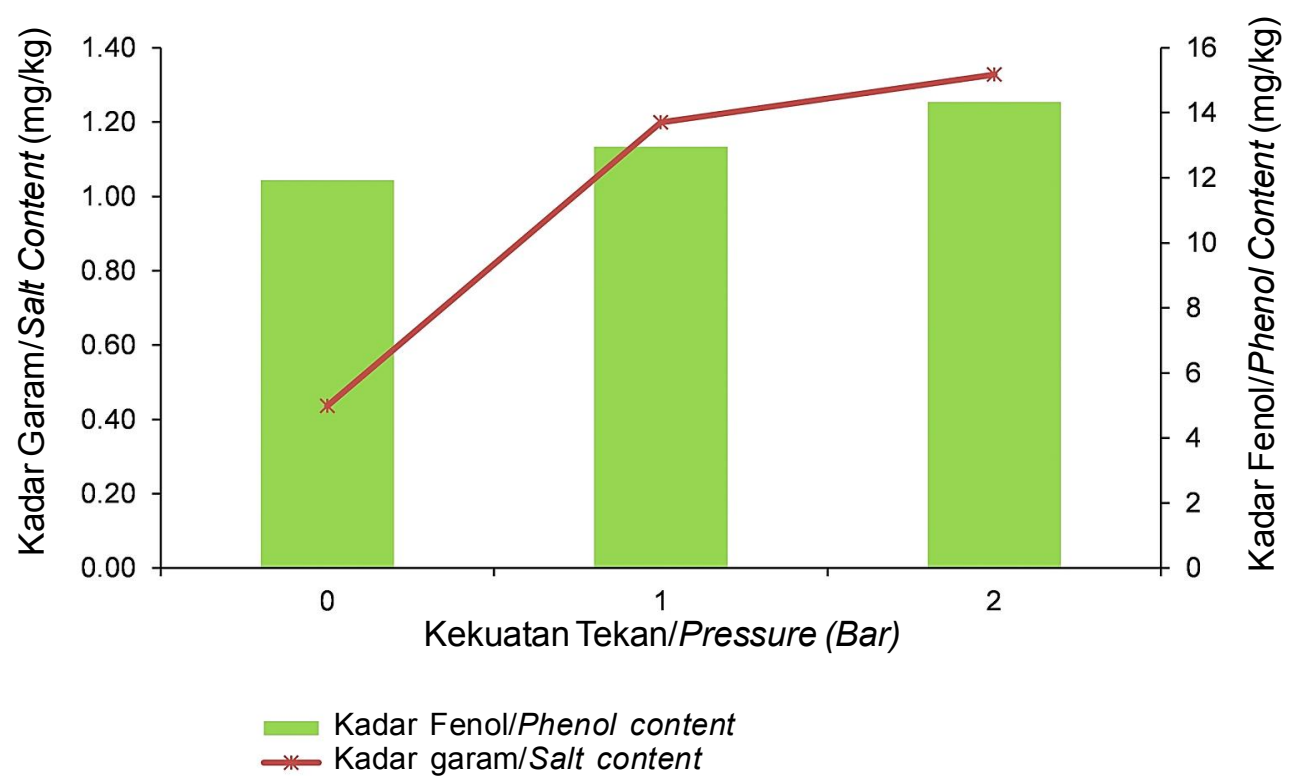

Keterangan/Note: Waktu vakum 10 menit/Vacuum time 10 minutes Waktu impregnasi 15 menit//mpregnation time 15 minutes Tingkat vakum $-76 \mathrm{cmHg} /$ Vacuum level $-76 \mathrm{cmHg}$

Gambar 5. Pengaruh tekanan terhadap kadar garam dan fenol fillet ikan. Figure 5. Effect of pressure to salt and phenol content of fish fillet. 
Tabel 3. Efektivitas metode impregnasi vakum

Table 3. Effectiveness of vacuum impregnation methods

\begin{tabular}{lcc}
\hline \multicolumn{1}{c}{ Parameter/Parameters } & $\begin{array}{c}\text { Metode Perendaman/ } \\
\text { Immersion Method }\end{array}$ & $\begin{array}{c}\text { Metode Impregnasi Vakum/ } \\
\text { Vacuum Impregnation Method * }\end{array}$ \\
\hline Waktu proses (menit)/Process period (minutes) & 60.00 & 15.00 \\
Kadar fenol/Phenol content (mg/100 g) & 2.95 & 15.18 \\
Kadar garam/Salt content (\%) & 0.40 & 1.25 \\
\hline
\end{tabular}

*) kekuatan tekan 2 bar, vakum 10 menit , $-76 \mathrm{cmHg}$

tekanan pada bahan yang telah divakum menjadikan larutan osmotik yang terintroduksi ke dalam bahan semakin besar, namun pada titik tertentu akan statis karena kondisi matrik yang kosong dalam sel bahan sudah terisi penuh.

Paramater-parameter yang diamati pada penelitian ini memberikan dasar yang kuat bahwa introduksi larutan osmotik (larutan garam dan asap cair) dapat dilakukan pada produk perikanan dengan menggunakan alat impregnasi vakum. Tabel 3 menunjukkan bahwa introduksi larutan garam dan fenol dengan metode perendaman selama 60 menit diperoleh kadar fenol sebesar 2,95 mg/100 g dan kadar garam sebesar $0,4 \%$ sedangkan dengan metode impregnasi dihasilkan kadar fenol sebesar 15,18 mg/ $100 \mathrm{~g}$ dan kadar garam sebesar $1,25 \%$ dalam waktu 15 menit. Waktu proses introduksi yang lebih cepat tersebut diakibatkan oleh karena bahan telah mengeluarkan udara dan air pada rongga-rongga sel, sehingga larutan osmotik lebih cepat terserap menggatikan material yang keluar sebelumnya (Panarese et al., 2013).

\section{KESIMPULAN}

Rancang bangun alat impregnasi vakum yang telah dirancang dengan 3 tangki atau tabung yaitu tangki penyimpanan, tangki vakum dan tangki pengaduk, masing-masing mempunyai kapasitas maksimal 130, 70 , dan $60 \mathrm{I}$. Alat tersebut menghasilkan kekuatan vakum maksimal $-76 \mathrm{cmHg}$ dalam waktu 9,15 menit sedangkan kekuatan tekan /impregnasinya maksimal 8 Bar dapat dicapai dalam waktu 38,70 menit. Sistem aliran bahan (larutan osmotik) pada alat menggunakan sistem pompa dan gravitasi. Prinsip kerja alat impregnasi vakum adalah mengkondisikan tekanan udara dalam tangki vakum menjadi lebih tinggi maupun lebih rendah dari tekanan normal atmosfer.

Hasil uji performansi menunjukkan bahwa alat impregnasi vakum tersebut mampu mengintroduksikan larutan garam dan asap cair ke dalam filet ikan nila lebih efisien dibandingkan dengan tanpa menggunakan alat. Dalam waktu 10 menit vakum dan
15 menit impregnasi mampu mengintroduksikan larutan garam sebanyak $1,25 \%$ dan fenol $15,18 \mathrm{mg} /$ $\mathrm{kg}$ sedangkan dengan perendaman selama 60 menit hanya mampu menyerap 0,4\% larutan garam dan 2,95 $\mathrm{mg} / \mathrm{kgfenol}$.

\section{DAFTAR PUSTAKA}

Barat, J.M., Grau, R., Montero, A., Chiralt, A., \& Fito, P. (1998). Feasibility of brining of ham for curing. In A. Diestre \& J.M. monfort (Eds.), Meat consumption and culture (Vol.II, pp. 970-971). Institute of Food Agricultural and Technology (IRTA) and EUROCARNE.

Betoret, N., Puente, L., Diaz, M.J., Pagan, M.J., Garcia, M.J., Gras, M.L., Martinez Monzo, J., \& Fito, P. (2003). Development of probiotic-enriched dried fruits by vacuum impregnation. Journal of Food Engineering. 56(2-3): 273-277.

Bugueno, G., Escriche, I., Chiralt, A., Perez-Juan, M., Setta, J.A., \& Camacho, M.M. (2001). Use of Impregnasi vakum in Smoked Salmon Manufacturing. Osmotic Dehydration \& Vacuum Impregnation. Application in Food Industries. Chapter 17. 195-206. Technomic Publishing Co., Inc. Lancaster. Basel.

Burg, S.P. 2014. Hypobaric Storage in Food Industry. Chapter 3-gas and Vapor Mass Transfer at A low pressure. Academic press. Elsivier. Uk

[BSN] Badan Standarisasi Nasional. (2009). SNI 2721.1:2009. Standar Mutu Ikan Asin. Badan Standarisasi Nasional. Jakarta.

[BSN]. Badan Standarisasi Nasional. (1991). SNI 012359-1991. Produk Perikanan, Penentuan Kadar Garam. Badan Standarisasi Nasional. Jakarta

Cardinal, M., Knockaert, C., Torrisen, O., Sigurgislado, S., Mrkre, T., Thomassen, M., \& Vallet, J.L. (2001). Relation of smoking parameters to the yield, colour and sensory quality of smoke atlantik salmon (Salmo salar). Food Research International. 81: 85-90.

Chaijan, M. (2011). Physicochemical change of tilapia (Oreochromis niloticus) muscle during salting. Food Chemistry. 129: 1201-1210.

Chiralt, A., Fito, P., Barat, J.M., Andrés, A., GonzálezMartínez, C., Escriche, I., \& Camacho, M.M. (2001). Use of vacuum impregnation in food salting process. Journal of Food Engineering. 49(2-3): 141-151. 
Fito, P. (1994). Modelling of vacuum osmotic dehydration of food. Journal of Food Engineering. 22: 313-328.

Girard, J.P. (1992). Smoking in Technology of Meat and Meat Produk. Girard, J.P. (ed). Ellis Horwood. New York.

Guamis, B., Trujillo, A.J., Ferragut, V., Chiralt, A., Andres, A., and Fito, P. (1997). Ripening control of Manchego type cheese salted by brine vacuum impregnation. International Dairy Journal. 7(2-3): 185-192.

Guillemin, A., Degraeve, P., Noel, C., \& Saurel, R. (2008). Infûuence of impregnation solution viscosity and osmolarity on solute uptake during vacuum impregnation of apple cubes (var. Granny Smith). Journal of Food Engineering. 86(4): 475-483.

Hong, S.S., Khan, W., Park, Y.K., \& Shin, Y.H. (2013). Analysis of pressure distribution for the various gas flow vacuum system in the range from $1 \mathrm{~Pa}$ to 133 Pa. Measurement. 46: 851-854.

Igual, M., Castello, M.L., Ortola, M.D., \& Andreas, A. (2008). Influence of vacuum impregnation on respiration rate, mechanical and optical properties of cut persimmon. Journal of Food Engineering. 86: 315-483.

Jeon, M. \& Zhao, Y. (2005). Honey in combination with impregnasi vakum toprevent enzymatic browning of fresh-cut apples. Journal of Food Science and Nutrition. 56(3): 165-176.

Laurindo, J.B., Stringari, G., Paes, S., \& Carcioû, B.A.M. (2007). Experimental determination of the dynamics of impregnasi vakum of apples. Journal of Food Science. 72: E470-E475.

Panarese, V., Dejmek, P., Rocculia, P., \& Galindo, F.G. (2013). Microscopic studies providing insight into the mechanisms of mass transfer in vacuum impregnation. Innovative Food Science and Emerging Technologies. 18: 169-176

Park, S.-I., Zhao, Y., Leonard, S.W., \& Traber, M.G. (2005). Vitamin $E$ and mineral fortiûcation in fresh-cut apples (Fuji) using impregnasi vakum. Nutrition and Food Science. 35(6): 393-402.

Rahmani, R., Yunianto, Y., \& Martati, E. (2007). Pengaruh metode penggaraman basah terhadap karakteristik produk ikan asin gabus (Ophiocephalus striatus). Jurnal Teknologi Pertanian Universitas Brawijaya. 8 (3): 142-152

Serot, T., Baron., Knockaert, C., \& Vallet, J.L. (2004). Effect of smoking processes on the content of 10 major phenolic compounds in smoked fillets of hearing (Cuplea harengus). Food Chemistry. 85(01): 111120.

SMEWW. (2005). 5530-Phenols. B.D. Standard Methods for The Examination of Water and Wastewater 21th edition.

Silvana V., Anino, Daniela, M. Salvatori, Stella, M., \& Alzamora. (2006). Changes in calcium level and mechanical properties of apple tissue due to impregnation with calcium salts. Food Research International. 39: 154-164.

Schulze, B., Peth, S., Maria, H.E., \& Schwarz, K. (2012). The inûuence of vacuum impregnation on the fortiûcation of apple parenchyma with quercetin derivatives in combination with pore structures X-ray analysis. Journal of Food Engineering. 109: 380387

Xie, J. \& Zhao, Y. (2003). Nutritional enrichment of fresh apple (Royal Gala) by vacuum impregnation. Journal of Food Science and Nutrition. 54(5): 387-398. 